\title{
Relationship Between Teachers' Academic Advancement and Work Performance in Public Primary Schools in Mumias West Sub-County Kenya
}

\author{
Rose Atoni *, Mukara Joyce ${ }^{\text {** }}$, Jeniffer Munyua ** \\ * Lecturer Of Education, The Catholic University Of Eastern Africa,Kenya \\ ** Senior Lecturer The Catholic University Of Eastern Africa,Kenya \\ DOI: 10.29322/IJSRP.11.07.2021.p11567 \\ http://dx.doi.org/10.29322/IJSRP.11.07.2021.p11567
}

\begin{abstract}
Primary school teachers' pursuit of higher academic qualifications of degrees and diplomas goes hand in hand with upgrading and updating of their skills and abilities, which should be of consequence to the quality of their work performance. The purpose of this study was to examine the influence of primary school teachers' pursuit of academic advancement on work performance among public primary schools in Mumias West sub county, Kenya. The study was guided by correlational design. The population targeted by the study included 846 primary school teachers and 47 deputy head teachers of the 47 public primary schools in Mumias West sub-county of Kakamega county, Kenya. Respondents included 20 head teachers, 20 deputy head teachers and 240 teachers randomly sampled from selected schools. Data was obtained by use of questionnaire and document analysis guides. It was analyzed descriptively using frequencies and percentages. Hypothesis was tested using t-test. The study found that: the number of teachers who had advanced in their academics to attain diplomas and degrees was higher than those who had not; the main reason why teachers pursued academic advancement was to position themselves for promotion; the teachers' mean rating on their job performance was above average; teachers who had advanced academically to attain higher academic qualifications had a higher work performance rating. The study concluded that teachers' academic advancement had a positive influence on work performance among public primary schools in Mumias West SubCounty, Kenya. The study recommends that the government should recognize and reward higher academic qualifications attained by primary school teachers; the Ministry of Education should create and operationalize policies that can encourage primary school teachers to pursue higher academic qualifications; school administrators should create an enabling environment in schools that can eliminate gender disparities in work performance. The overall necessity of this aspect of professional advancement is grounded in the fact that the quality of a teacher influences the entire learning process.
\end{abstract}

Index Terms- Academic Advancement : Work Performance

\section{INTRODUCTION}

$\mathrm{G}$ lobally, academic advancement of teachers has been tied Jintricately to acquisition of skills and capacity that should be of consequence to the quality of work performance. This is because academic advancement updates and upgrades teachers' skills, knowledge and capacity, whose application can translate to quality teaching and learning outcomes. As Owan and Agunwa (2019) argued, a nation rises only in direct proportion to the quality of its teachers. It is thus salient that the importance of academic advancement can neither be underestimated nor ignored. According to Smith (2010), academic advancement enhances teacher work performance, enables teachers to meet external evaluation standards, and satiates one's internal drive to learn and improve self. The overall necessity of this aspect of professional advancement is, however, anchored in the fact that the quality of a teacher influences the whole learning process (Maphoso \& Mahlo, 2015). The changing needs of learners from time to time and place to place, coupled with the emerging challenges encountered by teachers in the profession make it necessary that teachers should engage in professional advancement so as to remain relevant in the marketplace.

Academic advancement has been defined differently by different researchers. Darling-Hammond, Hyler, and Gardner (2017) defined it as structured professional learning that brings about changes in teacher knowledge and practices, and improvements in student learning outcomes. Earlier, OECD (2009) stated that this advancement involves activities that develop an individual's skills, knowledge, expertise and other characteristics as a teacher. Such activities may happen in a formal learning institution such as a university, resulting in academic qualifications of higher degrees or diplomas. Chambulila (2013), while explaining how 'Quality enhancement in teacher education' can be achieved among teacher-educators, defined academic advancement as "formal academic and professional advancement courses aiming at equipping educators with relevant and up to date knowledge and competencies essential for quality enhancement". General professional advancement can also happen through informal and non-formal arrangements. These include peertutoring, collaboration between schools, mentor-mentee relationships, in-service workshops and seminars. Interestingly, even Facebook groups have been found to be a potential platform that can enhance teachers' professional development (Bett \&Makewa, 2018). Namamba and Rao (2017) therefore defined professional development simply as "formal and informal increase in knowledge and skills". 
In Canada, Price and Reichert (2017) conducted a study, which indicated that professional advancement produced job satisfaction. In Indonesia, Anitasari and Retnawati (2018) found that teachers pursued academic advancement for varied intrinsic and extrinsic reasons, and not necessarily for enhancement of their work performance. In Nigeria, an earlier study by Abe (2014) also indicated that teachers' qualifications were significantly correlated with students' performance in mathematics. The need and purpose of academic advancement can thus not be underestimated.

In Kenya, the number of primary school teachers pursuing and obtaining higher qualifications of degrees and diplomas is on an uptick (Waweru, 2016). This is expected to translate to higher work performance rating among the teachers involved, since studies have revealed that teacher academic qualification has an influence on pupils' performance. Ojera (2016) found that students taught by teachers with higher academic qualifications performed better in KCSE examinations in Migori county, Kenya than those taught by teachers with lower qualifications. Pupils' performance in KCPE examinations in Mumias sub-county, however, has remained low (Wanjala \& Osendo, 2019). This is despite the increased pursuit of higher academic and professional qualifications among primary school teachers in the region (Waweru, 2016). This raises the question of whether or not academic advancement of the teachers in the sub-county contributes to their work performance. As opined by Hutabarat (2015), teachers are responsible for the success of students and student outcomes.

Workers are world over expected to do well in their jobs, whether they have been given an enabling environment or not. The situation is even more demanding in teaching profession where the society feels that teachers are owed nothing, and must therefore post excellent work performance (Maclean, 2018). As defined by Owan (2012), teachers' work performance refers to the degree to which teachers discharge their primary duty of teaching and learning, as well their general attitude towards the teaching profession. It is considered as the teacher's observable behaviors related to outcomes which are relevant to educational goals (Hutabarat, 2015).

Teachers' work performance in Kenya is assessed using Teacher Performance Appraisal and Development (TPAD) tool, which assesses teachers' work performance in terms of seven standards, namely: professional knowledge and application; time management; innovation and creativity in teaching; learner protection, safety, discipline and teacher conduct; promotion of co-curricular activities; professional development; and collaboration with parents/ guardians and stakeholders. However, the ultimate measure of a teacher's work performance is the pupils' learning outcomes in tests and examinations (Miller, Linn \& Gronlund, 2009). As argued by Okoti (2019), such information serves as machinery for not only judging teachers' performance, but also amending and improving educational practices.

Researchers have had interest in establishing the influence of higher academic qualifications resultant from academic advancement on teachers' work performance. Abe (2014) conducted a study in Nigeria to examine the "effect of teachers' academic qualifications on students' performance in Mathematics". Three hundred students were randomly selected from ten schools that were purposively selected from sixteen secondary schools in Ikere Local Government Area of Ekiti State and used as sample for the study. The qualification of the teachers was used as the criteria for selection of mathematics teachers. The three hypotheses in the study were tested using t-test statistic.

The results of the study showed that a significant difference existed in the performances of students taught by professional teachers and non-professional teachers, between students taught by teachers with Nigeria Certificate in Education (NCE) and B.Sc. Ed. teachers and also between B.Sc. teachers and B.Sc. Ed. teachers at $\mathrm{P}<0.05$. The study recommended that, only qualified mathematics teachers should be allowed to teach mathematics at the secondary school level. While the holders of Nigeria Certificate in Education (NCE) should be allowed to proceed in their education either through part-time or study leave likewise teachers without teaching qualification should be advice to pursue their Post Graduate Diploma in Education (PGDE). This may improve their teaching method in order to improve the performance of students in mathematics. This recommendation for teachers of lower qualifications enrolling for professional advancement courses so as to enhance their work performance is the basis of the current study that investigated whether and how academic advancement influences work performance of primary school teachers in Mumias West sub-county.

Another study was also conducted in Nigeria by Maclean (2018) investigating the relationship between in-service training and teachers' job performance in public senior secondary schools in Rivers State. The study used correlational research design. The sample consisted of 845 public senior secondary school teachers who were drawn through stratified random sampling techniques from a population of 8452 teachers. Six research questions guided the study. Data was collected using questionnaires titled "Teachers Inservice Training Questionnaire (TITQ)" and "Teachers Job Performance Questionnaire (TJPQ)". The data was analysed by use of means and standard deviations and Pearson Product Moment Correlation. The study findings showed that teachers mean rating on their participation in in-service training programmes was above average, teacher mean rating of their job performance was above average, and there were strong positive and significant relationships between teacher learning, teacher growth, teacher needs, teachers' collaboration and job performance in public senior secondary schools in Rivers State. From the study it was concluded that in-service training had positive impact on teacher job performance in public senior secondary schools. Based on the finding some of the recommendations were made: opportunities for in-service training programme should be made available to all categories of teachers, all stakeholders should revitalize the organization of regular seminars, workshops and conferences for old and newly employed practicing teachers and government should bear the financial burden for teachers' in-service training programmes by making budgeting allocation for that purpose. Also, distance supported elearning at school level should be encouraged. Unlike this study in Nigeria which narrowed down on in-service trainings by means of seminars, workshops and conferences, the current study in Mumias- West, Kenya, considered academic advancement that happens in universities and colleges leading to award of higher academic qualifications of degrees and diplomas.

In South Africa, Maphoso and Mahlo (2015) investigated the relationship between teacher qualifications and pupil academic achievement. The research sought to investigate if teacher 
qualifications differed significantly among learners in boarding and in non-boarding schools, and if they had significant relationship with academic achievement among grade 12 learners of the Capricorn District in the Limpopo Province, South Africa. A simple random sample was drawn from the population of 339 schools, comprising of 51 principals, 158 teachers and 290 learners from 51 schools. "School Environmental Questionnaire (SEQ)" was used to collect data to determine whether the school was boarding or non-boarding, along with the qualifications of teachers. The Capricorn District Academic Summary Report of the Grade 12 results collected data on academic achievement.

The t-test results showed no significant difference in qualifications of teachers between boarding and non-boarding schools and no significant difference between low and high achieving schools in qualifications of teachers. The study concluded that there were no significant differences in qualifications of teachers between boarding and non-boarding schools. There was also no significant difference in qualifications of teachers between schools with low and high academic achievement. The study also indicated that there was no relationship between qualifications of teachers and academic achievement of Grade 12 learners in the Capricorn District of the Limpopo Province in South Africa. It was recommended that in hiring effective teachers, school management should not look only at qualifications of teachers, since teacher qualification was not the sole contributor in academic achievement.

Musau and Abere (2015) investigated "Teacher qualification and students' academic performance in science mathematics and technology subjects in Kenya". This was out of concern that performance in Science, Mathematics and Technology subjects among students in Kitui County, Kenya had perpetually been unsatisfactory. The aim of the study was to look into the extent to which teacher qualification influenced students' academic performance in SMT subjects. The study used ex-post-facto research design. Random sampling was used to select eight secondary schools in Kitui county. It included eight head teachers, 40 teachers of SMT subjects and 600 candidates who sat for the Kenya Certificate of Secondary Education (KCSE) in the year 2012. Data were collected using questionnaires and document analysis. It was analyzed using descriptive and inferential statistical tools.

The study found that there was no significant difference in means between teacher qualification and students' performance in SMT subjects at form four level $F(1,37)=0.017, p>0.05$. The findings of the study further revealed that majority of the teachers of SMT subjects were trained graduates, most of them had attended in-service or refresher courses which resulted in slight improvement in the students' performance in SMT subjects. The study recommended that more regular in-service and refresher training of SMT subject teachers be organized to enable them embrace and conform to the emerging technologies in pedagogy. This study was done in 2015 among secondary schools. The current study is needful to find out if the situation has changed over time, and if it is different among primary schools as compared to secondary schools.

Waweru (2016) conducted a study on influence of teacher qualifications on teaching performance in public primary schools in Mukurweini sub-county, Kenya. This was due to the concern that the number of teachers with diplomas and degrees at primary school level was increasing exponentially due to the opportunities available to pursue higher education. However, low performance in Kenya Certificate of Primary Education has been recorded for years especially in the study area. The objectives of the study were to examine the influence of teacher qualification on; quality of instructional preparation, instructional strategies, effective assessment and evaluation of pupils and management of student discipline. The study employed descriptive survey research design. The target population was 66 head teachers and 198 diploma teacher holders. Thirty-three schools with diploma holders previously certificate holders and 33 head teachers were purposively sampled. Ninety-nine teachers, three per school were selected through simple random sampling.

The study collected data using questionnaires and interview schedules. Qualitative data was content analyzed and some responses quoted directly. Frequency and percentages were used to analyze quantitative data. Findings from teachers and head teachers indicated that higher qualification improved teaching performance on instructional preparation, adoption of better teaching strategies, assessment and evaluation of students and maintenance of student discipline. The study recommended that there was need to; encourage and facilitate teachers to go for higher training for purposes of increasing their competency, promptly upgrade and remunerate upon attainment of higher qualification and finally implement the Ministry policy on elevating certificate teacher training to diploma level.

Ojera (2016) investigated the "impact of teacher qualification on pupils' academic achievement in Kenya Certificate of Primary Education in public primary schools of Migori County, Kenya". This was out of the concern that Migori county public primary schools on average had been performing poorly in KCPE. The study adopted descriptive survey design. The study targeted 723 head-teachers, 4406 teachers and 16 QASO officials in Migori County. Simple random sampling was used to pick 251 head teachers while purposive sampling was used to pick 251 teachers and 16 QASO officers. The instruments of data collection were questionnaires and interview schedules. The data was analyzed using frequency counts, percentages, standard deviations, means and regression analysis.

The study found that majority of primary school teachers in Migori county were Diploma holders (35.8\%), followed by Bachelor's Degree (28.7\%), Certificate (25.9\%) and finally Master's Degree (9.6\%). There was no Doctor of Philosophy (PhD) holder. The study also found that students taught by teachers with higher qualifications performed better than those taught by teacher with lower qualifications in KCSE examinations. The study recommended that the government should provide more incentives to encourage more teachers to pursue further education as this had potential to benefit pupils. The finding that students taught by teachers with higher qualifications performed better than those taught by teacher with lower qualifications in KCSE examinations informs the purpose and theoretical framework of the current study. However, since purposive sampling technique was used to obtain teachers who participated in this study, it limits the extent to which the research findings of the study can be generalized. The current researcher thus used simple random sampling so as to enhance generalizability of the research findings. Further still, Ojera (2016) study used KCSE results of the previous year's pupils, who may 
have been taught by different teachers, to draw its conclusions. The current study used results of internal tests and exams of pupils currently being taught by the teachers who were involved in the study. In addition to academic performance, the current study also evaluated teachers' work performance using the standards of the TPAD tool.

\section{RESULTS}

\section{T-test results for relationship between academic advancement and work performance Group Statistics}

\begin{tabular}{llrlll}
\hline & \multicolumn{2}{l}{$\begin{array}{l}\text { Have you ever advanced yourN } \\
\text { studies to attain a higher } \\
\text { academic qualification, after }\end{array}$} & Mean & Std. Deviation & Std. Error Mean \\
& $\begin{array}{l}\text { your first qualification as a } \\
\text { teacher? }\end{array}$ & 68 & 4.13 & .532 & .065 \\
\hline $\begin{array}{l}\text { Mean } \\
\text { performance }\end{array}$ & No & 36 & 3.78 & 1.043 & .174 \\
\hline
\end{tabular}

\section{Independent Samples Test}

Levene's Testt-test for Equality of Means

for Equality of

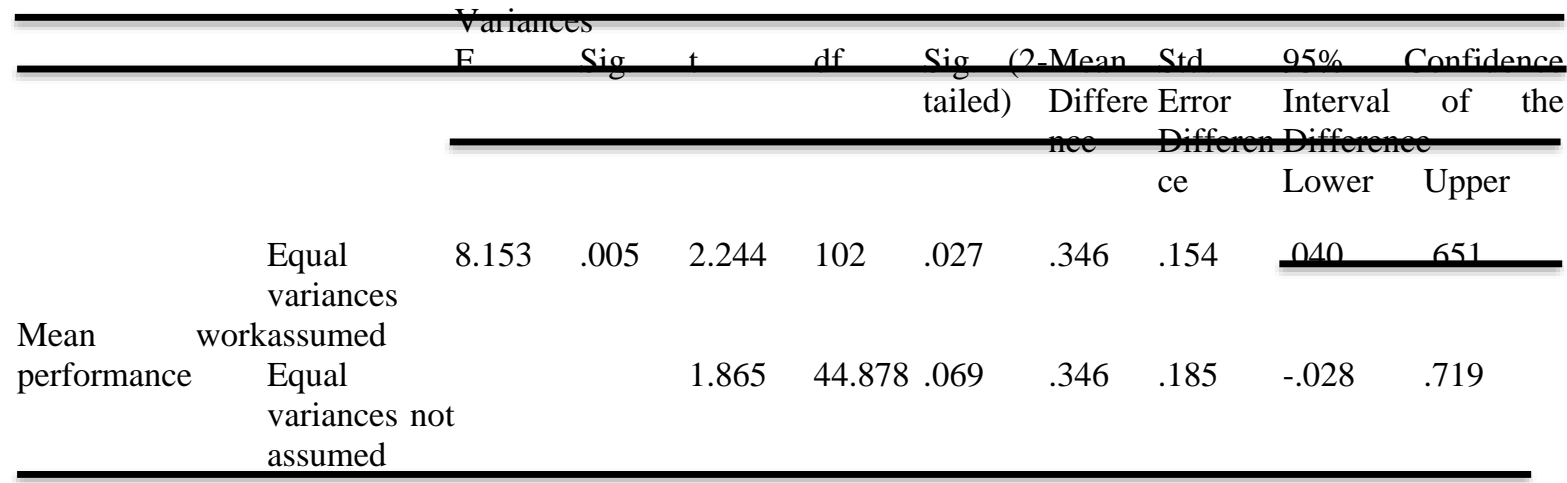

It was revealed that there was a significant difference in the means of work performance scores between teachers who had advanced in their academics $(\bar{X}=4.13, \mathrm{SD}=0.52)$ and those who had $\operatorname{not}(\bar{X}=3.78, \mathrm{SD}=1.043)$, with $\mathrm{t}(102)=2.244$ and $\mathrm{p}=0.027$ at $\alpha=0.05$.

The null hypothesis $\left(\mathrm{H}_{0}\right)$ that "There is no significant relationship between academic advancement and work performance of teachers among public primary schools in Mumias West sub-county" was thus rejected. It was therefore accepted that there is a significant relationship between academic advancement and work performance of teachers among public primary schools in Mumias West sub-county. Teachers who had advanced to obtain higher academic qualifications had a higher work performance rating.

These findings agree with Bulimo, Ndiku and Maiyo (2016) whose study found that continuing professional development improved teacher competencies. This is also consistent with Blumberg and Pringle (1982) theory of work performance, which maintains that work performance is a function of capacity. Through academic advancement, teachers build their capacity, hence enhancing their work performance. Abe (2014) found that teachers' qualifications had improved work performance which reflected in improved students' achievement. According to Maphoso and Mahlo (2015), the overall necessity of this aspect of professional advancement is anchored in the fact that the quality of a teacher influences the whole learning process. Their study however, found no relationship between qualifications of teachers and academic achievement.

\section{CONCLUSION}

On the basis of the above findings, the study makes the following conclusions:

i. The number of teachers who have advanced in their academics is higher than those who have not.

ii. Most of the primary school teachers who have advanced their studies have attained Diplomas

iii. Majority of head teachers and deputy head teachers have advanced in their studies.

iv. The main reason why teachers pursue academic advancement is to position themselves for promotion.

v. Other reasons why teachers pursue academic advancement include preparing for other opportunities outside teaching, becoming better teachers, growing in knowledge, increasing job satisfaction and matching achievements of others.

vi. The mean rating of teachers' work performance in Mumias West subcounty is above average. 
vii. There is a significant relationship between teacher experience and work performance.

Teachers with more years of work experience have higher work performance than those who are relatively new in the teaching profession

\section{RECOMMENDATION}

i. The government should recognize and reward higher academic qualifications attained by primary school teachers.

ii. In consultation with relevant stakeholders, the government should create and operationalize policies that can encourage primary school teachers to pursue higher academic qualifications

\section{REFERENCES}

[1] Abe, T.O. (2014). Effect of Teachers' Qualifications on Students' Performance in Mathematics. Sky Journal of Education, 2, 10-14. '

[2] Anitasari, E. \& Retnawati, H. (2018). The Motivation of Mathematics Teachers in Continuing Professional Development. Journal of Physics: Conference Series, 1097, 01-08

[3] Arop F. O., Owan, V. J. \& Madukwe E. C. (2019). Human Resource Management and Teachers' Job Performance in Secondary Schools in Akamkpa Local Government Area of Cross River State, Nigeria. International Journal of Social Sciences and Management Research, 5(2), 27 34.

[4] Armstrong, M. (2009). Human resource management: Theory and practice: London: Bath Press Limited.

[5] Bett, H., \& Makewa, L. (2018). Can Facebook groups enhance continuing professional development of teachers? Lessons from Kenya. Asia-Pacific Journal of Teacher Education, 1-15.

[6] Bulimo, W. A., Ndiku, J. M., \& Maiyo, J. K. (2016). Contribution of continuing professional development for school managers on teacher management competencies of secondary school managers in Kenya.

[7] Blumberg, M., \& Pringle, C. D. (1982). The missing opportunity in organizational research- some implications for a theory of work performance. Academy of Management Review, 7(4), 560 - 569.

[8] Chambulila, C. (2013). Quality enhancement in teacher education: Tanzanian teacher educators' conceptions and experiences. Åbo: Åbo Akademi University Press.

[9] Darling-Hammond, L., Hyler, M.E., \& Gardner, M. (2017). Effective Teacher Professional Development (research brief). Palo Alto, CA: Learning Policy Institute. [Google Scholar]

[10] Hutabarat, W. (2015a). Do Organizational Structure and Organizational Culture Affect Teachers' Work Motivation to Some Extent. International Journal of Sciences: Basic and Applied Research (IJSBAR), 20(2), 350-362.

[11] Isiye, M. C. (2015). Factors Influencing the Academic Performance of Day Scholars in Public Secondary Schools in Kenya: A Case of Mumias West Sub-County. Masters Thesis, University of Nairobi
[12] Maphoso LS, Mahlo D. Teacher qualifications and pupil academic achievement. JSoc Sci 2015;42:51-8.

[13] Miller, M. D., Linn, R., \& Gronlund, N. (2009). Measurement and evaluation in teaching (10th ed.). Upper Saddle River, NJ: Merrill, Prentice Hall.

[14] Musau, L. M. \& Abere, M. J. (2015). Teacher qualification and students' academic performance in science mathematics and technology subjects in Kenya. International Journal of Educational Administration and Policy Studies, 7, 83-89.

[15] Namamba, A., \& Rao, C. (2017). Preparation and Professional Development of Teachers' Educators in Tanzania: Current Practices and Prospects. Journal of Education and Practice, 8,136-145.

[16] OECD (2009). Creating effective teaching and learning environments: First results from TALIS. Paris: OECD.

[17] Ojera, A. D. (2016). Impact of Teacher Qualification on Pupils' Academic Achievement in Kenya Certificate of Primary Education in Public Primary Schools of Migori County, Kenya. World Journal of Educational Research (3), $1-20$

[18] Okoti, D. (2019). Effects of Students' Pursuit in Sports Betting on Learning Process among Public Secondary Schools in Mumias-East Sub-County, Kenya. Masters Thesis, Catholic University of Eastern Africa.

[19] Owan, V.J., 2012. Some causes of poor performance of pupils in primary school mathematics. A case study in. Akamkpa Local Government Area of Cross River State, Nigeria. NCE Project Submitted to School of Education, Cross River State College of Education, Akamkpa. Available from https://goo.gl/NTTxqc.

[20] Owan, V. J \& Agunwa, J. N (2019). Principals’ Administrative Competence and Teachers' Work Performance in Secondary Schools in Calabar Education Zone of Cross River State, Nigeria. Humanities and Social Sciences Letters (7), 20-28

[21] Price, S., \& Reichert, C. (2017). The importance of continuing professional development to career satisfaction and patient care: meeting the needs of novice to mid-to late- career nurses throughout their career span. Administrative Sciences, 7(2), 17.

[22] Smith, P. K. (2010). Professional development of teacher educators. In P. Peterson, E.

[23] Wanjala, G. \& Osendo, L. P. (2019). Appraising Teacher Creativity and Collaborative Skills in Public Primary Schools in Mumias-East Subcounty, Kenya. International Journal of Education and Research, 7, 207-218.

[24] Waweru, H. W. (2016) Influence of Teacher Qualifications on Teaching Performance in Public Primary Schools in Mukurweini, Kenya. Karatina University

\section{AUTHORS}

First Author - Rose Atoni rose.atoni@yahoo.com, Lecturer Of Education, The Catholic University Of Eastern Africa,Kenya Second Author - Mukara Joyce Malesi

(Joycemalesi@Yahoo.Com), Senior Lecturer The Catholic University Of Eastern Africa, Kenya

Third Author - Jeniffer Munyua (Jmunyua@Gmail.Com), Senior Lecturer The Catholic University Of Eastern Africa, Kenya 